\title{
Optimization of Village Fund Supervision in Sukoharjo Regency
}

\author{
Sigit Pambudi ${ }^{1}$, Kismartini Kismartini ${ }^{2}$, Budi Puspo Priyadi ${ }^{3}$ \\ \{sigit.pambudi46@gmail.com ${ }^{1}$, kismartini@live.undip.ac.id ${ }^{2}$, budipuspo@gmail.com ${ }^{3}$ \} \\ Magister Ilmu Administrasi Fakultas Ilmu Politik dan Ilmu Sosial Universitas Diponegoro 1,2,3
}

\begin{abstract}
Village Fund is central government attemp to carry out development from the village. To ensure the effectiveness, efficiency, and accuracy of Village Funf Management, supervision is needed, one of them from local government. Sukoharjo Regency has village fund supervision policy through functional supervision by the Inspectorate. This study was conducted to analyze how supervision policy of Village Fund Implementation in Sukoharjo and determine the factor that stimulate and inhibit. The research approach is descriptive qualitative. The results show the implementation of village fund supervision policy by the Inspectorate of Sukoharjo Regency is not optimal yet and there are inhibiting factors and supporting its implementation. The author recommeds: (1) formulate a mechanism for supervision Village Fund with reference to the Village Fund Supervision Guidelines, (2) conducting socialization and training related to supervision of Village Fund by utilizing information technology.
\end{abstract}

Keywords: supervision of village fund, optimalizing, policy implementation.

\section{Introduction}

As an autonomous region within the territory of the regional government, the village becomes the object of the ongoing fiscal decentralization system obtained from both the central and regional governments. This is in line with the 2014 - 2019 RPJMN and 2020 - 2024 RPJMN documents, where villages are the focus of national development. With the issuance of Government Regulation Number 60 of 2014 as amended by Government Regulation Number 22 of 2015 and Government Regulation Number 8 of 2016 concerning Village Funds Sourced from the State Revenue and Expenditure Budget, villages receive Village Funds.

The Indonesian government for five years in the 2015 - 2019 period has planned to provide Village Fund assistance with a budget value of Rp. , in 2018 it was Rp. 59.86 trillion, and in 2019 it was Rp. 70.00 trillion. Based on this data, it can be seen that the Village Fund tends to increase from year to year, while for the 2020-2024 period, the Village Fund will continue to be rolled out to villages because the government continues to make villages the focus of development. According to the 2020-2024 RPJMN, transfers to the regions and the 2024 Village Fund range from 4.9 to 4.9. 5.1\% of Gross Domestic Product (GDP).

To oversee the use of the Village Fund, the government is obliged to carry out supervision to ensure the effective and efficient use of the Village Fund and in accordance with the provisions of the legislation. Referring to Government Regulation Number 12 of 2017 concerning Guidance and Supervision of Regional Government Administration in Article 17, to 
maintain village accountability, regents or mayors are assisted by regional inspectorates to carry out guidance and supervision of villages. Furthermore, the Minister of Home Affairs mandates regional heads to conduct guidance and supervision of village financial management whose implementation is coordinated to the Regent/Mayor who is coordinated through the Regional Inspectorate as the Regional Government Internal Supervisory Apparatus.[9] The Minister of Home Affairs through Circular Number 700/1281/A.1/13 dated December 22, 2016 provides guidelines for supervision of the Village Fund for the Regional Inspectorate which contains the program and steps for monitoring the Village Fund. The purpose of the supervision of the Village Fund is to provide adequate assurance that the management of the Village Fund has been carried out in accordance with the provisions, particularly related to the right location, the right conditions, the right channel, the right amount, and the right use.

In its implementation, there are still many problems in managing the Village Fund, where the village government is one of the institutions that is vulnerable to corrupt practices in line with the increasing sources of village income. This is because the budget managed is quite large but the capacity of the village apparatus in financial management is limited. Corruption in the village fund budget was ranked third (48 cases with a state loss of IDR 10.4 billion). However, in 2017 , this number tends to increase, with village budget corruption being ranked first (98 cases with a state loss of IDR 39.3 billion). In 2018, based on sector, village budget corruption was still ranked first with 96 cases with a state loss of IDR 37.2 billion. On the other hand, there is the potential for mal-administration in the management of Village Funds in the last four years, including deviations from procedures for using Village Funds, delays in distributing Village Funds, the village government and related parties being unprofessional in preparing APBDes and LPJ. provide good public services. The number of cases of corruption in the Village Budget shows an increase from year to year.

The Sukoharjo Regency Inspectorate is a Government Internal Supervisory Apparatus (APIP) that has supervised the management of Village Funds in the Sukoharjo Regency environment since 2016. The number of villages receiving Village Funds is 150 villages spread over 11 sub-districts. The Village Fund supervision policy is regulated in [6] Regent Regulation Number 18 of 2017 concerning Procedures for Distribution and Management of Village Funds in Chapter IX Article 29 (c) which states that the Inspectorate shall carry out functional supervision over the implementation of Village Funds. The implementation of Village Fund supervision is part of a comprehensive village inspection in general.

At the level of implementation of the Village Fund policy in Sukoharjo Regency during 2016 s.d. 2019, there are still problems. The delay in the preparation of the 2018 FY APBDes occurred in 18 villages, which until May 2018 had not determined the APBDes which resulted in the inability to disburse Village Funds in the 18 villages. On the accountability side, there are still delays in the delivery of accountability for the delay in determining the APBDes, delays in the completion of accountability for both the Village Fund and the 2016 FY 2016 Village Fund Allocation of Rp. In Fiscal Year 2017, there were 48 villages that were late in submitting Village Fund accountability.[4] Furthermore, in the implementation of the Village Fund management supervision policy, problems were still found, including the existing regulations that did not fully support good supervision and the implementation of village fund management supervision by the government was also inadequate.

The implementation of supervision over the management of the Village Fund is one form of implementation of public policies in the field of supervision. Policy implementation is an action carried out by the government and the private sector both individually and in groups to achieve certain targets as set out in the policy.[11] According to George Edward III (1980)[2], policy implementation is a complex activity in which there are many factors that influence the 
success of a policy implementation. To study it, George Edward III started by asking two questions, namely "What is the precondition for successful policy implementation?" and "What are the primary obstacles to successful policy implementation?". To answer that question, George Edward III argues that the success of policy implementation is influenced by four factors, namely communication, resources, attitude of implementers, and bureaucratic structure.

Based on the description of the problems mentioned above, it is interesting to study further how the implementation of the supervision policy for the management of the Village Fund in Sukoharjo Regency by the Regional Inspectorate and the supporting and inhibiting factors of the implementation of the supervision policy are carried out.

\section{Methodology}

This research was conducted using descriptive qualitative research, namely making a description or describing facts or events systematically and in depth regarding the implementation of the Village Fund management supervision policy as regulated in Perbup Number 18 of 2017 and the factors supporting and inhibiting the implementation of the supervision policy in Sukoharjo Regency. Data collection techniques used in this study include data analysis and interviews. The collected data were analyzed descriptively qualitatively, namely by describing and explaining the research results in the form of spoken and written words from a number of qualitative data. In analyzing the data, the researcher uses the data analysis model from Miles and Huberman (2007)[8], in which there are three activity flows that occur simultaneously, namely data condensation, data display and drawing and verifying conclusions. Qualitative data analysis was carried out simultaneously with the ongoing data collection process, meaning that these activities were carried out before entering the field, while in the field, and after finishing in the field.

\section{Finding and Discussion}

\subsection{Implementation of Village Fund Management Supervision Policies in Sukoharjo Regency}

Public policy implementation according to Pressman and Wil is the activity of completing or implementing a public policy that has been determined/approved by using means (tools) to achieve policy objectives [10]. Anderson [10] suggests that policy implementation is the application of policies by government administrative apparatus to the problem. [10], while Grindel explains that policy implementation is a general process of administrative action that can be investigated at a certain program level. [1] According to (Purwanto, 2015), implementation is basically an activity in order to deliver regulatory output (to deliver policy output) carried out by implementers to the target group (target group) in terms of achieving the goals of a policy. [7]

Supervision or controlling is an activity aimed at ensuring that the implementation of activities is in accordance with the plan. Supervision also detects violations early, which can then be avoided with more fatal consequences and before a bigger impact occurs. [3] On the supervision of the management of Village Funds in Sukoharjo Regency, the Sukoharjo Regency Government through Article 23 paragraph 3 and Article 29 point $\mathrm{c}$ of Regent Regulation 
Number 18 of 2017 mandates the Inspectorate to carry out supervision of the distribution and use of Village Funds in the form of functional supervision.

Based on the results of the study, it can be seen that the Sukoharjo Regency Inspectorate has implemented a supervisory policy on the management of the Village Fund starting when the Village Fund was rolled out in 2015. However, the supervision activities carried out by the Sukoharjo Regency Inspectorate have not been optimal and have not referred to the Village Fund supervision policy as contained in the Circular Letter of the Minister of Home Affairs Number 700/1281/A.1/13 dated December 23, 2016 concerning Guidelines for Supervision of Village Funds.[9]

In terms of planning, the inspectorate has a policy of supervision and the Annual Supervision Work Program (PKPT) which is determined annually by the Regent of Sukoharjo. The policy includes planning for internal supervision of local and village governments in general. In this case, the supervision of the management of the Village Fund is integrated with general village supervision or comprehensive village financial management. Supervision is carried out through examination or audit. The detailed inspection steps are regulated in the Audit Program which will later be used as a guideline for the auditors/inspectors of the Inspectorate to carry out inspection activities. The Inspectorate Inspector in carrying out supervision is based on the Supervision Assignment Letter signed by the Inspector. The assignment letter contains the object of the inspection and the personnel who will carry out the inspection and the period of the inspection.

The results showed that the inspection program for village supervision did not refer to the Village Fund Supervision Guidelines as stated in Circular Letter Number 700/1281/A.1/13 dated December 23, 2016 concerning Guidelines for Supervision of Village Funds[9]. The Village Fund supervision guidelines, among other things, regulate the steps for examining Village Funds including pre-distribution, distribution and use, and post-distribution. In addition to regulating the inspection steps, the Village Fund supervision guidelines contain the competence of the examiner and matters of concern. Matters of concern include the preparation of a risk-based PKPT and the use of the Village Financial System (SISKEUDES) application for a desk audit supervisory technique.

In terms of implementation, the Inspectorate supervises Village Funds within the framework of general village supervision, including village administration, village financial administration, and village accountability. The implementation of supervision through inspection activities by inspectorate personnel is based on an inspection assignment letter made by the Inspector with reference to the PKPT that has been made.

During the period of the assignment letter, the inspectorate auditor team conducted a field inspection of the village. After conducting the examination, the inspectorate auditor team makes notes on the results of the examination, namely in the form of examination findings. Inspection findings are the implementation of activities that are not in accordance with existing criteria or regulations. Next, the inspection team of the inspectorate prepares the Inspection Result Manuscript to the village for further clarification and response by the village head. Through the submission of this NHP, the Village Head can find out the mistakes that exist and convey the next corrective steps.

During 2015 s.d. 2019, the Sukoharjo Regency Inspectorate carried out village inspections on 151 inspection objects (obrik). Obrik details can be seen in the table below. 
Tabel 1. Village Obrik at the Sukoharjo Regency Inspectorate 2015 - 2020.

\begin{tabular}{cccccc}
\hline No & Year & $\begin{array}{c}\text { General Financial } \\
\text { Management }\end{array}$ & Village Fund & $\begin{array}{c}\text { Non Village } \\
\text { Fund }\end{array}$ & Total \\
\hline 1 & 2015 & 29 & - & 0 & 29 \\
2 & 2016 & 44 & - & - & 44 \\
3 & 2017 & 29 & - & - & 29 \\
4 & 2018 & 12 & - & 18 & 30 \\
5 & 2019 & - & 17 & 2 & 19 \\
& Total & $\mathbf{1 1 4}$ & $\mathbf{1 7}$ & $\mathbf{2 0}$ & $\mathbf{1 5 1}$ \\
\hline
\end{tabular}

Source: PKPT Inspectorate Year 2015 s.d. 2019.

As shown in table 1, the Village Fund audit is part of the general financial management audit in 2015 s.d. 2018 with 114 examination objects, while in 2019, the Village Fund examination became a separate object of examination, namely 17 objects of examination. The 2015 - 2019 Village Fund Audits were 131 objects of inspection carried out in 119 villages. The frequency of Village Fund inspections during the 2015 - 2019 period was carried out with a frequency of 1 time in 107 villages and a frequency of 2 times in 12 villages. When compared with the total number of villages, which is 150 villages, it can be seen that there are 31 villages that have not been examined regarding the management of the Village Fund.

According to the BPK LHP[4], from 75 village inspection units (2015 to 2017), 59 village regular LHPs have contained the suitability of using DD and/or ADD. However, the remaining 16 regular village LHPs have not been able to identify the results of monitoring the suitability of using Village Funds and Village Fund Allocations, of which 7 LHPs have not included the amount of Village Funds in general village financial data.

The results of the interview with the Inspector stated "for the years 2016 s.d. 2018, the inspection of village funds is a comprehensive examination in which the Village Fund is one part of the audit, the inspection steps are general in nature and have not been guided by the SE Minister of Home Affairs. However, in 2019, we made a special examination of the Village Fund and adopted the steps as stated in the SE in the implementation of our examination."

Based on the results of the research above, it can be concluded that the implementation of supervision over the management of Village Funds at the inspectorate has not referred to the Guidelines for Supervision of Village Funds, especially in 2016 until. 2018. Functional examination of the Village Fund management has not covered the population of 150 villages during the period 2015 s.d. 2019.

In terms of reporting and follow-up, the Sukoharjo Regency Inspectorate made a Village Supervision Report containing general information, an overview of supervision, inspection findings containing conditions, criteria, causes and effects as well as recommendations addressed to the village concerned for improvement or restoration of village finances. Recommendations must be followed up by the village concerned within 30 days after submitting the LHP. The Sukoharjo Regency Inspectorate submits a Supervision Result Report to the Sukoharjo Regent. Then, the Regent makes an internal correction letter to the village concerned containing the findings and recommendations of the results of the examination by attaching the Inspection Report which has been signed by the Inspector of Sukoharjo Regency. The Sukoharjo Regency Inspectorate carries out follow-up monitoring of the results of the Inspectorate's inspection to the Village. 


\subsection{Supporting and Inhibiting Factors Implementing Village Fund Management Supervision Policies in Sukoharjo Regency}

There are four factors that support and hinder, namely communication, resources, disposition of implementers, and bureaucratic structure. Here's the explanation:

\section{Communication}

Communication is one of the supporting factors in implementing the Village Fund management supervision policy. George $C$ Edward stated that the success of the communication process can be seen in three factors, namely the process of transmitting information, clarity of information, and consistency of orders from the process of transmitting information in the form of socialization. The Sukoharjo Regency Inspectorate in terms of the information transmission process and the consistency of orders is considered to support the implementation of the Village Fund management supervision policy. Consistency of orders can be seen in the consistency of village inspection objects in the annual supervision policy set by the Sukoharjo Regent, as well as the Annual Supervision Work Program (PKPT) and the implementation of supervision. However, in terms of clarity of information, supervision over the management of the Village Fund is still general in nature. This is because the supervision in the form of inspections by the Inspectorate is comprehensive in nature over the village, not only on the Village Fund. In addition, the Inspectorate has also not implemented a Village Fund supervision policy in accordance with the Circular of the Minister of Home Affairs Number 700/1281/A.1/13 dated December 23, 2016 regarding Guidelines for Supervision of Village Funds [9]. Furthermore, the Technical Guidelines for Supervision of Village Funds have not been revealed in an internal regulation related to supervision within the Sukoharjo Regency.

\section{Resource}

There are three aspects of the resource factor, namely Human Resources, Financial Resources, and Infrastructure. Aspects of Human Resources are still considered to be an inhibiting factor in the Implementation of Village Fund Management Supervision Policies. In terms of the quantity of human resources, the Sukoharjo Regency Inspectorate in carrying out the supervision policy for the management of the Village Fund has not been optimal in terms of the number of human resources. As a result, supervision has not been able to reach all villages. In addition, the large workload on supervision of OPD and schools receiving BOS Funds or other additional tasks makes the supervision policy for Village Fund management not maximized. In terms of quality, the Sukoharjo Regency Inspectorate is not yet fully optimal. This can be seen in the lack of training related to the implementation of Village Fund supervision as well as civil engineering personnel for the guidance and supervision of infrastructure activities, while the supporting factors in the Implementation of the Policy for Development and Supervision of Village Fund Management are Financial Resources and the availability of facilities and infrastructure. This can be shown in the determination of the budget that takes into account the existing capacity and the availability of relatively adequate infrastructure.

\section{Implementing Disposition}

The disposition of the implementer can be translated as a serious attitude to the implementer of the policy based on the will, desire, and inclination to realize the objectives of the policy (Edward II, in Widodo, 2007: 104). Related to disposition, there are elements of response, including understanding of the implementer, then implementing action (Van Metter and Van Horn in Agustinus, 2006: 94). The disposition of the implementers in the Village Fund Management Supervision Policy is considered to be still less than optimal. This can be seen 
from the understanding and implementation of the supervision of the Village Fund which is still general in nature and is not concentrated on the Village Fund alone. The Inspectorate understands the supervision of the Village Fund in a comprehensive village inspection. The Inspectorate in supervising the 2016 to 2016 Village Funds. 2018 has not referred to the Circular Letter of the Ministry of Home Affairs Number 700/1281/A.1/13 dated December 23, 2016 regarding Guidelines for Supervision of Village Funds[9]. The Inspectorate then began to refer to the Village Fund Supervision Guidelines for the 2019 Fiscal Year.

\section{Bureaucratic Structure}

The bureaucratic structure is a supporting factor in the implementation of the Village Fund management supervision policy from the aspect of organizational structure, cooperation between teams and coordination between teams. The Sukoharjo Regency Inspectorate in carrying out the supervision policy is based on an examination assignment letter that appoints personnel to supervise the Village Fund consisting of the Responsible Person, namely the Sukoharjo Regency Inspector, Technical Controller, namely Assistant Inspector (Irban), Team Leader and Team Members, namely functional officials supervision. Cooperation between teams and coordination between teams is carried out every month by the Inspector, which is attended by all supervisors. Then during the pre-audit, namely the implementation of the technical supervision coordination meeting by the Technical Controller, Team Leader, and Team Members, at the time of the inspection by the Chair and Team Members, as well as at the time of reporting by the Inspector as the Person in Charge, Irban as the Technical Controller, and the Chairperson and Examining Team Members.

\section{Conclusion}

Based on the results of research on the implementation of the supervision policy for the management of the Village Fund in Sukoharjo Regency and based on the discussion in the previous chapter, it can be concluded that the implementation of the supervision policy for the management of the Village Fund in Sukoharjo Regency has been running but is still not optimal. Factors that hinder the policy of supervising the management of Village Funds, among others:

a) Clarity of communication on the implementation of supervision which is determined separately in the Circular Letter of the Minister of Home Affairs Number 700/1281/A.1/13 dated December 23, 2016 regarding Guidelines for Supervision of Village Funds[9]. Furthermore, the Technical Guidelines for Supervision of Village Funds have not been revealed in an internal regulation related to supervision within the Sukoharjo Regency. This has implications for the supervision carried out on financial management in general.

b)Limited human resources both in quantity and quality. This can be seen in the implementation of the Village Fund supervision over the last five years that has not covered all villages and villages only get supervision every five years and are limited to the scope of one village budget year. In addition, it can also be seen from the lack of technical personnel who carry out infrastructure inspections and the lack of training related to village supervision.

c) Implementing disposition on understanding and implementation, in which the supervision of the Village Fund is still general in nature and is not concentrated on the Village Fund alone. The Inspectorate understands the supervision of the Village Fund in a comprehensive village inspection. The Inspectorate in supervising the 2016 to 2016 Village Funds. 2018 has not 
referred to the Circular Letter of the Ministry of Home Affairs Number 700/1281/A.1/13 dated December 23, 2016 regarding Guidelines for Supervision of Village Funds[9]. The Inspectorate then began to refer to the Village Fund Supervision Guidelines for the 2019 Fiscal Year.

Factors that support the policy of supervising the management of the Village Fund, among others:

a) In terms of the information transmission process and the consistency of orders shown in the consistency of village inspection objects in the annual supervision policy set by the Sukoharjo Regent, as well as the Annual Monitoring Work Program (PKPT) and the implementation of supervision

b) Availability of facilities and infrastructure as well as budget in the implementation of supervision of Village Fund management.

c) The bureaucratic structure in the supervisory structure is adequate, namely the presence of a person in charge, technical controller, team leader, and members as well as the intensity of communication and coordination between the teams is adequate.

Based on the results of the study, the researchers provided suggestions or input as a consideration to the Sukoharjo Regency government in optimizing the Village Fund supervision policy, namely developing a work mechanism/SOP for Village Fund supervision by referring to the Village Fund Supervision Guidelines to be further outlined in the Sukoharjo Regency internal regulations as a derivative The existing Perbup and conduct socialization to inspectorate examiners, conduct training related to supervision of Village Fund management to inspectors at the Inspectorate, conduct training and conduct audit desk audits through information technology by utilizing the SISKEUDES application to expand the object of inspection of Village Fund management.

\section{References}

[1] Haedar Akib, Implementasi kebijakan: Apa, Mengapa dan Bagaimana. Jurnal Ilmiah Ilmu Administrasi Publik. 1(1): 1-11, 2012.

[2] Kamal Alamsyah, Kebijakan Publik Konsep dan Aplikasi. Bandung: Media Citra Mandiri Press, 2016.

[3] Bachrul Amiq, Aspek Hukum Pengawasan Pengelolaan Keuangan Daerah, Dalam Perspektif Penyelenggaraan Negara yang Bersih. Yogyakarta: Laks Bang Pressindo, 2010.

[4] BPK. Laporan Hasil Pemeriksaan Kinerja atas Efektivitas Pembinaan dan Pengawasan Pengelolaan Dana Desa dan Alokasi Dana Desa Tahun Anggaran 2015 s.d. Semester I 2018 pada Pemerintah Kabupaten Sukoharjo dan Instansi Terkait Lainnya di Sukoharjo. 2018.

[5] Peraturan Menteri Dalam Negeri Nomo 113 Tahun 2014 tentang Pengelolaan Keuangan Desa sebagaimana telah dirubah dalam Peraturan Menteri Dalam Negeri Nomor 20 Tahun 2018

[6] Peraturan Bupati Sukoharjo Nomor 18 Tahun 2017 tentang Tata Cara Penyaluran dan Pengelolaan Dana Desa.

[7] Purwanto, A. E. Implementasi Kebijakan Publik Konsep dan Aplikasinya di Indonesia. Yogyakarta: Gaya Media;2015.

[8] Miles, Matthew B., \& Huberman, A. Michael, Analisis data Kualitatif (Tjetjep Rohedi, Pentj), Jakarta: UI Press, 2007. 
[9] Surat Edaran Nomor 700/1281/A.1/13 tanggal 23 Desember 2016 yang ditujukan kepada Gubernur, Bupati, dan Walikota seluruh Indonesia dengan perihal Pedoman Pengawasan Dana Desa.

[10] Tachjan, Implementasi Kebijakan Publik, Bandung: AIPI Bandung, 2006.

[11] Budi Winarno, Kebijakan Publik: Teori, Proses, dan Studi Kasus. Jakarta: PT Buku Seru, 2012. 